\title{
SPEECH ACTS DALAM SERIAL TV GAME OF THRONES: KAJIAN \\ PRAGMATIK
}

\section{Christian T. Tumimomor}

christtum@gmail.com

\section{Djeinnie Imbang}

djeinnie@yahoo.com

Leika M. V. Kalangi

Leikamvk17@gmail.com

\section{Pasca Sarjana Program Studi Linguistik \\ Universitas Sam Ratulangi}

\begin{abstract}
This research focused on the illocutionary acts in Game of Thrones TV series. It aims to have a description of the illocutionary acts and to identify the utterances with its meaning in the show. In this study the data were analyzed through qualitative analysis, the data collected in this research are from the show's script of Game of Thrones Season 6 episode ten entitled "The Winds of Winter". The data are categorized and explained based on Austin's classification of illocutionary acts as the pioneer of this theory. The results of the data analysis showed that the illocutionary acts performed by the characters in the series are varies and included in Austin's classification of illocutionary acts which are verdictives, excersitives, commissives, behabitives and expositives. Based on the results, the illocutionary acts performed by the characters in the series are influenced by the speaker's or the addressee's status, it is indicated by how the nobles performed their illocutionary acts are different comparing to the peasants in the show. It could be concluded that the speaker's background or status are influential when performing illocutionary acts and to gain proper response from the addressee.
\end{abstract}

Key words: speech acts, illocutionary acts, game of thrones. 


\section{PENDAHULUAN}

Pada umumnya bahasa didefinisikan sebagai alat komunikasi, pemahaman ini sudah menjadi pengetahuan umum. Hornby (2010) mengatakan bahwa bahasa merupakan sistem komunikasi baik lisan maupun tulisan yang digunakan oleh masyarakat dalam suatu area. Bahasa merupakan sesuatu yang tidak bisa dilepaskan dari kehidupan manusia karena bahasa itu terlibat dalam setiap aktivitas bahkan pola pikir dan kebudayaan suatu masyrakat, Milhalicek dan Wilson (2011) pun menjelaskan kalau bahasa ‘menyentuh' segala aspek dalam kehidupan manusia, bahasa memberikan suara kepada pikiran dan juga mengekspresikan perasaan manusia. Berdasarkan penjelasan ini bisa disimpulkan bahwa bahasa merupakan alat yang digunakan manusia untuk mengekspresikan atau menyampaikan gagasan kepada orang lain dan betapa pentingnya peran bahasa dalam kehidupan manusia sehari-hari.

Pragmatik merupakan ilmu yang mempelajari cara seseorang mengekspresikan bahasa dalam situasi tertentu, terutama jika kata-kata yang digunakan memiliki maksud yang lain (Hornby, 2010) dari pernyataan ini bisa dipahami kalau pragmatik adalah ilmu yang berkaitan dengan makna yang diinterpretasi oleh pendengar, sejalan dengan penjelasan Yule (1996) yang juga menyatakan kalau bidang pragmatik berkaitan dengan interpretasi dari apa yang dimaksudkan oleh penutur di dalam konteks tertentu dan bagaimana konteks tersebut mempengaruhi makna tuturan. Tindak tutur merupakan salah satu bidang yang dikaji di dalam ilmu pragmatik.

Penelitian ini berfokus kepada tindak tutur ilokusi pada serial televisi Game of Thrones. Tindak tutur ilokusi sebagaimana dijelaskan oleh Yule (1996) merupakan dorongan komunikatif dari suatu tuturan, artinya ketika melakukan tindak tutur ilokusi setiap tuturan yang diucapkan oleh sang penutur pasti memiliki tujuan dan maksud untuk dilakukan oleh sang pendengar. Serial televisi Game of Thrones (GOT) yang memiliki setingan jaman abad 
pertengahan memiliki banyak dialog antar karakter yang disampaikan dengan cara yang unik karena dipengaruhi oleh status sosial oleh sang penutur.

Beberapa penelitian mengenai fenomena tindak tutur sudah pernah dilakukan, yang pertama penelitian yang dilakukan oleh Pranadjaja (2015) dengan judul "A Study of Speech acts in Glee S6" dalam penelitian ini dia menuliskan tindak tutur yang yang ditemukan kemudian dibagikan ke dalam lima bentuk tindak tutur ilokusi berdasarkn teori dari John Searle. Penelitian ini berfokus kepada tindak tutur yang disampaikan oleh karakter utama Rachel Berry. Dalam penelitian ini dijelaskan bahwa tindak tutur yang ditemukan sebagian besar terdiri dari direktif dan representatif, dan hampir tidak ditemukan deklaratif dalam setiap tuturan dari sang karakter utama. Dalam tahap penulisan data sang peneliti hanya menyediakan data dalam bentuk pernyataan dan kalimat tanpa menuliskan konteks dan situasi pernyataan itu dituturkan.

Penetlitian lainnya dilakukan oleh Jahdiah (2015) dengan judul "Implikatur dalam Wacana Kampanye Calon Legislatif Kabupaten Tanah Bumbu Periode 2019-2024”. Dalam penelitian ini penulis mengidentifikasi bentuk tindak tutur yang terkandung dalam penyampaian aspirasi oleh para caleg di kabupaten Tanah Bumbu, dan data-data tersebut diklasifikasi dan dianalisis menggunakan teori tindak tutur dari John Searle. Dalam penelitian tersebut peneliti menyimpulkan bahwa bentuk tindak tutur yang terdapat di dalam penyampaian aspirasi para caleg tersebut paling banyak terdiri atas jenis tindak tutur komisif yaitu berupa janji dan pernyataan kesanggupan.

Penelitian ini berbeda dengan penelitian yang dilakukan sebelumnya karena peneltian ini berfokus kepada dialog setiap karakter dalam serial televisi Game of Thrones dengan memperhatikan konteks dimana percakapan itu terjadi dan status sosial dari sang penutur selain 
itu penelitian ini juga menggunakan teori tindak tutur serta klasifikasi tindak tutur dari Austin (1962) sebagai pelopor dari teori ini.

Masalah yang akan dikaji dalam penelitian ini adalah bentuk-bentuk tindak tutur apa saja yang ditemukan dalam serial televisi Game of Thrones serta fungsi dan makna dari setiap tindak tutur tersebut.

\section{METODOLOGI PENELITIAN}

Penelitian ini menggunakan metode deskriptif kualitatif. Mahsun (2005: 257) menyatakan Penelitian kualitatif adalah adalah kegiatan yang beralngsung secara simultan dengan kegiatan analisis data. Artinya data-data yang ditemukan berupa tindak tutur pada dialog percakapan para tokoh dalam serial televise Game of Thrones, kemudian diidentifikasi dan diklasifikasi berdasarkan teori tindak tutur dari Austin (1962). Setelah itu data di analisis untuk memperoleh hasil dan membuat kesimpulan.

Penelitian ini tergolong sebagai penelitian kualitatif karena penelitian ini menggunakan metode deskriptif dan data yang dianalisis merupakan kata-kata, frasa atau kalimat. Bogdan dan Biklen (1982: 28) menyatakan "Qualitative research is descriptive, the data collectedare in the form of word or picture rather than numbers, the written result of the research contains quotations from the data illustrate and substantiate the presentation." Data yang diperoleh dalam penelitian ini berasal dari tuturan tokoh-tokoh dalam serial TV Game of Thrones S6 terlebih khusus episode terakhir yang tayang pada 26 Juni 2016 dengan judul "The Winds of Winter". Dalam mengumpulkan data, naskah dan film diamati dan dicatat untuk mendapatkan data yang tepat dan yang dibutuhkan untuk penyelesaian penelitian ini. 


\section{HASIL PENELITIAN DAN PEMBAHASAN}

\section{Hasil Penelitian}

A. Verdictives (verdiktif)

Data 1

Peserta : Walder Frey, Jaime Lannister

Situasi : Walder duduk di sebelah Jaime.

$$
\begin{array}{ll}
\text { Walder } & \text { : So the famous Blackfish killed by footsoldiers, eh? Legendary } \\
& \text { warrior, everyone said. } \\
\text { Jaime } & : \text { Have you done much fighting yourself, Lord Frey? } \\
\text { Walder } & : \text { I'm a bit old for all that. } \\
\text { Jaime } & : \text { No, but back in your day. } \\
\text { Walder } & : \text { The purpose of fighting is defeating your enemies, isn't it? } \\
& \text { I've defeated mine. Riverrun belonged to House Tully for a } \\
& \text { thousand years. Now it's mine. What do you call that? Victory. }
\end{array}
$$

Tuturan ini adalah pernyataan fakta sehingga dikategorikan sebagai tipe verdiktif dari tindak tutur ilokusi. Penutur menyatakan bahwa Riverrun untuk waktu yang lama telah dimiliki oleh House Tully, mantan tuannya, tetapi karena kerja sama mereka dengan House Lannister mereka dapat mengalahkan House Tully dan mendapatkan kastil itu sebagai bentuk kepercayaan dan aliansi antara House Lannister dan House Frey. Ucapan ini dihitung sebagai pernyataan fakta karena pengetahuan penutur tentang sejarah negaranya, 
dan karena kastil itu telah diserahkan kepada sang penutur yang menjadikan kalimat ini sah.

B. Excersitives (eksersitif)

\section{Data 2}

Peserta : Cersei Lannister, Qyburn

Situasi : Cersei and Qyburn berdiri di samping tubuh Tommen, tubuhnya tertutup dengan kain

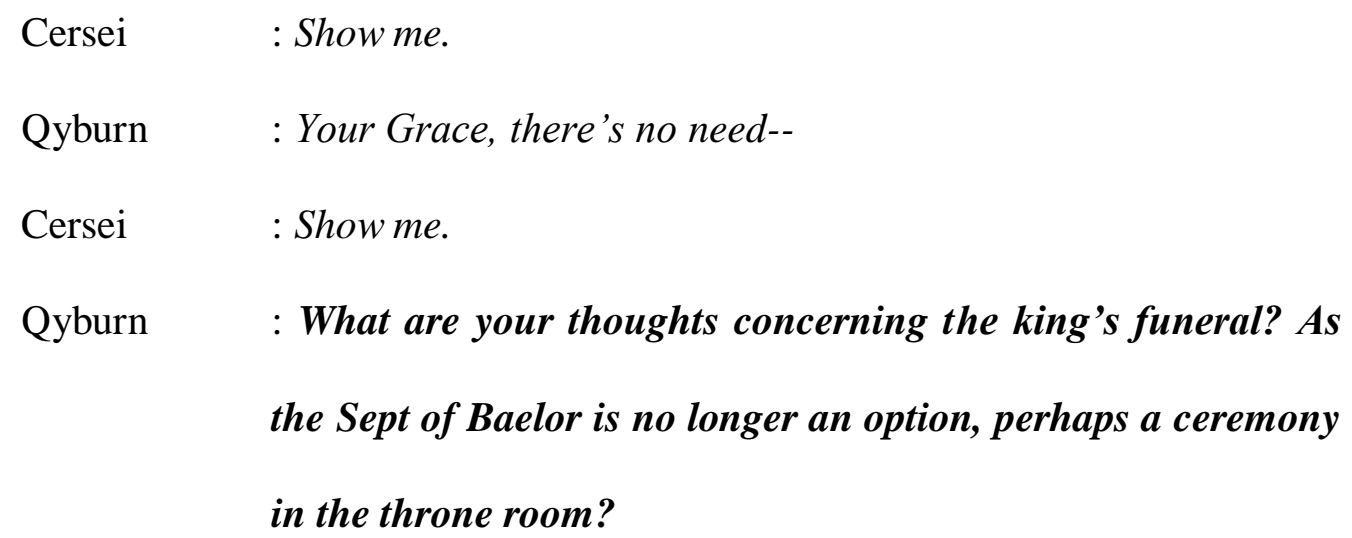

Cersei $\quad$ : He should be with his grandfather, his brother, his sister. Burn him and bury his ashes where the sept once stood.

Tuturan ini adalah tindakan menyarankan yang diklasifikasikan sebagai tindak ilokusi eksersitif. Sang penutur menyarankan Cersei tentang di mana mereka harus menguburkan putranya, karena tempat di mana mereka biasanya menguburkan anggota keluarga kerajaan telah habis dibakar, ia memberikan beberapa alternatif lain yang mungkin sesuai dengan keinginan Ratu. Ucapan ini dianggap sebagai saran karena ucapan pembicara terdengar seperti sebuah usul dengan menghadirkan opsi kepada Cersei tanpa ada paksaan di balik ucapannya.

C. Commissives (komisif)

Data 3

Peserta : Glover, Jon Snow 
Situasi : Jon Snow duduk di meja tinggi, perwakilan dari Klan Utara, Vale, dan Wildlings berkumpul di ruang makan. Salah satu bangsawan menyatakan Jon sebagai Raja baru di Utara.

Glover : I did not fight beside you on the field and I will regret that until my dying day. A man can only admit when he was wrong and ask forgiveness.

Jon Snow : There's nothing to forgive, my lord.

Glover : There will be more fights to come. House Glover will stand behind House Stark as we have for a thousand years. And I will stand behind Jon Snow... the King in the North!

Tuturan ini adalah tindakan berjanji yang diidentifikasi sebagai jenis tindak ilokusi komisif. Glover yang merupakan salah satu bangsawan besar di utara mengikrarkan House-nya untuk mendukung House Stark dalam perang yang akan datang, ia menjanjikan House-nya berarti bahwa ia menerima Jon sebagai Rajanya dan bersumpah untuk melayani Jon dan House Stark dengan cara apa pun yang diperlukan. Ucapan ini dianggap sebagai tindakan berjanji karena pembicara bersumpah untuk mendedikasikan hidupnya untuk Jon dan mendukung perjuangannya.

D. Behabitives (behabitif)

\section{Data 4}

Peserta : Benjen Stark, Meera Reed, Bran Stark

Situasi : Benjen menatap Wall sementara Bran dan Meera berada di dekatnya.

Benjen : This is where I leave you.

Meera $\quad$ : You're not coming with us? 

Benjen $\quad$ : The Wall is not just ice and stone. Ancient spells were carved into its foundations. Strong magic to protect men from what lies beyond. And while it stands, the dead cannot pass. I cannot pass.
Meera : Where will you go?
Benjen : The great war is coming and I still fight for the living. I'll do what I can ... as long as I can.
Brann : Thank you, Uncle Benjen.
Benjen : I wish you both good fortune.

Tuturan di atas adalah tindakan berterima kasih yang termasuk dalam jenis tindak ilokusi behabitif. Penutur mengucapkan kalimat ini kepada pamannya setelah dia mengantar mereka melalui hutan dan kemudian membawa mereka ke perbatasan. Ucapan ini adalah ungkapan terima kasih untuk pamannya yang telah menyelamatkan mereka dari bahaya.

E. Ekspositives (ekspositif)

\section{Data 5}

Peserta : Margaery Tyrell, High Sparrow

Situasi : Margaery melihat ke sekeliling kerumunan. kemudian menghadapi high sparrow

Margaery : There's something wrong.

High Sparrow : You have nothing to fear, Your Grace. The trial will begin shortly.

Margaery $\quad$ : Cersei is not here. Tommen is not here. Why do you think they are not here?

High Sparrow : If the accused is not here, she will be tried regardless. We cannot escape the justice of the gods- 
Margaery : Forget about the bloody gods and listen to what I'm telling

you. Cersei understands the consequences of her absence and

she is absent anyway, which means she does not intend to

suffer those consequences. The trial can wait. We all need to

leave.

Tuturan tersebut termasuk ke dalam tindakan membantah dan memberikan asumsi yang termasuk dalam jenis tindakan ilokusi ekspositif. Berdasarkan fakta bahwa Cersei dan Tommen terlambat untuk menghadiri persidangan, penutur menyimpulkan ketidakhadiran mereka berarti bahwa Cersei tidak pernah memiliki niat untuk menghadiri persidangannya sejak awal, yang berarti bahwa Cersei memiliki rencana lain untuk menyelamatkan dirinya. Margaery percaya bahwa Cersei merencanakan sesuatu yang dapat menyebabkan bahaya bagi mereka yang ada disana.

\section{Pembahasan}

Penelitian ini menggunakan teori tindak tutur dari Austin (1962) sebagai pelopor teori tindak tutur untuk mengidentifikasi jenis serta menginterpretasi makna dan fungsi tindak tutur.

\section{Pragmatik}

Yule (1996: 4) menyatakan bahwa pragmatik adalah ilmu yang mempelajarihubungan antara bentuk-bentuk linguistik dan pengguna dari bentuk-bentuk tersebut. Mempelajari pragmatik memiliki beberapa keunggulan tersendiri, diantaranya kita dapat memahami maksud dari penutur, seperti yang sudah dijelaskan bahwa "pragmatics is a study of speaker meaning" (Yule 1996: 3) yang dimaksudkan dengan pernyataan itu bahwa pragmatik merupakan ilmu yang mempelajari makna yang disampaikan oleh penutur dan bagaimana tuturan tersebut diinterpretasi oleh mitra tutur. Verhaar (1996) juga menyatakan bahwa 
pragmatik merupakan cabang ilmu yang membahas mengenai apa yang termasuk struktur bahasa sebagai alat komunikasi antara penutur dan pendengar.

\section{Tindak Tutur}

Yule (1996: 47) menyatakan "actions performed via utterances are generally called speech acts", pernyataan Yule ini sejalan dengan dengan pendapat Tarrigan (1990) bahwa tuturan yang berkaitan dengan tindak tutur memiliki tujuan dan maksud, artinya kedua belah pihak yaitu penutur dan mitra tutur terkibat di dalam suatu kegiatan atau fenomena tutur yang memiliki tujuan.

Austin (1962) membagi tindak tutur terbagi atas tiga level berdasarkan tingkatnya, ketiga level tersebut adalah tindak lokusi, ilokusi dan perlokusi. Penelitian ini hanya berfokus kepada tindak tutur ilokusi.

Tindak Ilokusi

Tindak tutur ilokusi merupakan tindak tutur yang berfungsi baik untuk mengatakan sesuatu dan juga untuk melakukan sesuatu, atau disebut juga sebagai the act of doing something (Austin, 1962). Dalam bertutur, penutur tidak hanya mengekspresikan ucapan yang kosong akan tetapi setiap tuturan itu memiliki 'force' yang bertujuan untuk memberikan pengaruh kepada mitra tutur. Tuturan-tuturan tersebut dapat memiliki maksud untuk menyuruh, meminta tolong dan lain sebagainya tergantung dari maksud sang penutur yang diinterpretasi oleh pendengar. Yule (1996) juga berpendapat bahwa tindak ilokusi merupakan the illocutionary force of an utterance. Pendapat Yule tersebut didasari dari pernyataan Austin (1962) sebagai pelopor dari teori ini. Austin mengatakan bahwa setiap tindak ilokusi memiliki illocutionary force. Austin (1962: 150-151) mengklasifikasikan tindak tutur menjadi lima, yaitu:

\section{Verdictives (verdiktif)}

Austin (1962: 150) menjelaskan "verdictives, are typified by the giving of a verdict, as the name implies" Tetapi tuturan-tuturan yang termasuk ke dalam jenis tindak tutur ini 
tidak harus final; tuturan tersebut bisa saja berupa sebuah pernyataan fakta, perkiraan, perhitungan, atau penilaian.

\section{Excersitives (eksersitif)}

Menurut Austin (1962: 150) "exercitives, are the exercising of powers, rights, or influence." Eksersitif berkaitan dengan pengaplikasian pengaruh, hak dan kekuasaan. Yang termasuk kedalam tindak tutur ini adalah menunjuk, memberikan suara, memberi perintah, mendesak, memberi nasihat, memberi peringatan dll.

\section{Commissives (Komisif)}

Austin (1962: 150) berpendapat "commissives, are typified by promising or otherwise undertaking;" jenis tindak tutur yang tergolong sebagai komisif adalah pernyataan sumpah maupun berjanji, tindak tutur komisif mengikat sang penutur kepada suatu aksi yang akan dilakukan di masa yang akan datang.

4. Behabitives (behabitif)

Austin (1962: 151) menyatakan "behabitives, are a very miscellaneous group, and have to do with attitudes and social behavior." Tindak tutur yang diklasifikasi sebagai behabitif adalah meminta maaf, memberi selamat, memuji, turut berduka cita, mengutuk, dan menantang.

5. Expositives (ekspositif)

Klasifikasi tindak tutur yang terakhir adalah ekspositif, Austin (1962: 151) menyatakan "expositives, are difficult to define. They make plain how our utterances fit into the course of an argument or conversation, how we are using words, or, in general, are expository." Yang termasuk ke dalam tindak tutur ini adalah memberikan bantahan, memberikan ilustrasi, memberikan asumsi, memberikan pengakuan dll.

\section{SIMPULAN}


Tindak ilokusi yang ditemukan dalam Game of Thrones membuktikan bahwa tindak ilokusi diucapkan dengan tujuan tertentu yang dimaksudkan oleh penutur untuk mempengaruhi pendengar dalam beberapa cara agar mitra tutur melakukan tindakan tertentu atau membuat mereka bereaksi, yaitu memberikan informasi, menyatakan pendapat, memberikan perintah, bahkan berjanji untuk melakukan suatu tindakan di masa depan.

Berasal dari tema acara yang berlatar abad pertengahan, ditunjukkan bahwa posisi atau status pembicara juga dapat memiliki kontribusi dalam tuturan mereka di mana kaum bangsawan dan rakyat jelata memiliki cara khusus untuk melakukan tindakan ilokusi mereka. Fakta ini menunjukkan bagaimana tindak tutur bekerja secara berbeda untuk penutur dengan latar belakang yang berbeda.

Berdasarkan hasil penelitian yang diperoleh peneliti mengemukakan beberapa saran sebagai berikut

- Diharapkan ada penelitian lanjutan membahas mengenai kajian ilmu pragmatik terlebih tindak tutur yang menggunakan teori maupun pendekatan dari ahli lain.

- Diharapkan pada pembaca untuk mencari tahu lebih dalam lagi mengenai kajian ilmu pragmatik maupun tindak tutur.

\section{Daftar Pustaka}

Austin, J.L.1962. How to do Things with Words. Oxford: Oxford University Press.

Bogdan, R. and Biklen, S.1992. Qualitative Research for Education: An Introduction to Theory and Method. $2^{\text {nd }}$ ed. Boston: Allyn and Bacon, Inc.

Hornby, A.S. 2010. Oxford Advanced Learner's Dictionary $8^{\text {th }}$ Edition. Oxford: Oxford University Press 
Jahdiah.2019. Implikatur dalam Wacana Kampanye Calon Legislatif Kabupaten Tanah Bumbu Periode 2019-2024: Kajian Pragmatik.

Milhalicek, V. and Wilson, C.2011. Language Files. $11^{\text {th }}$ ed. Columbus: The Ohio State University Press.

Pranadjaja, A.F.2015. A Study of Speech Acts in Glee Season 6. Tondano.

Searle, J.1969. Speech Acts: An Essay in the Philosophy of Language. Cambridge: Cambridge University Press.

Searle, J.1976. A Classification of Illocutionary Acts. Language in Society. Cambridge: Cambridge University Press.

Searle, J.1979. Expression and Meaning. Studies in the Theory of Speech Acts. Cambridge: Cambridge University Press.

Tarigan, H.1990. Pengajaran Pragmatik. Bandung:Angkasa Yule, G.1985. The Study of Language. Cambridge: Cambridge University Press.

Yule, G.1996. Pragmatics. Oxford: Oxford University Press. 